\title{
Continuous monitoring of hydrogen and carbon dioxide at Mt Etna
}

\author{
Roberto M.R. Di Martino ${ }^{\text {a,* }}$, Marco Camarda ${ }^{\text {b }}$, Sergio Gurrieri ${ }^{\text {b }}$, Mariano Valenza ${ }^{\text {a }}$ \\ a Dipartimento DiSTeM, Università di Palermo, via Archirafi 36, I-90123 Palermo, Italy \\ b Istituto Nazionale di Geofisica e Vulcanologia, Sezione di Palermo - via Ugo La Malfa 153, I-90146 Palermo, Italy
}

\section{A R T I C L E I N F O}

\section{Article history:}

Received 26 October 2012

Received in revised form 22 July 2013

Accepted 13 August 2013

Available online 20 August 2013

Editor: D.B. Dingwell

\section{Keywords:}

Soil $\mathrm{CO}_{2}$ flux

$\mathrm{H}_{2}$ monitoring

$\mathrm{H}_{2}$ fuel cell

Mt Etna

\begin{abstract}
A B S T R A C T
This study assessed the use of an $\mathrm{H}_{2}$ fuel cell as an $\mathrm{H}_{2}$-selective sensor for volcano monitoring. The resolution, repeatability, and cross-sensitivity of the sensor were investigated and evaluated under known laboratory conditions. A tailor-made device was developed and used for continuously monitoring $\mathrm{H}_{2}$ and $\mathrm{CO}_{2}$ at $\mathrm{Mt}$ Etna throughout 2009 and 2010. The temporal variations of both parameters were strongly correlated with the evolution of the volcanic activity during the monitoring period. In particular, the $\mathrm{CO}_{2}$ flux exhibited long-term variations, while $\mathrm{H}_{2}$ exhibited pulses immediately before the explosive activity that occurred at Mt Etna during 2010
\end{abstract}

(c) 2013 Elsevier B.V. All rights reserved.

\section{Introduction}

Geochemical monitoring of soil gases has been widely used as a powerful tool for geothermal exploration (Badalamenti et al., 1984, 1988; Bertami et al., 1990; Finlayson, 1992; Chiodini et al., 1998), exploiting oil and gas reserves (Gregory and Durrance, 1985; McCarthy and Reimer, 1986), and other applications such as earthquake prediction (Irwin and Barnes, 1980; King, 1980; Wakita et al., 1980; Sugisaki et al., 1983; Oskarsson, 1984; Satake et al., 1984; Sato et al., 1984; Wakita, 1996; Salazar et al., 2002; Kameda et al., 2003; Giammanco et al., 2006) and volcano surveillance (Sato and McGee, 1982; Badalamenti et al., 1991; Baubron et al., 1991; Barberi and Carapezza, 1994; Valenza, 1994; Giammanco et al., 1995a, 1995b; Giammanco et al., 1996; Granieri et al., 2009; Federico et al., 2011; Camarda et al., 2012). Gases of deep origin can escape toward the earth's surface along preferential pathways such as fractures and crustal faults. Most gases are emitted in volcanic areas via geysers, thermal springs, crater plumes, and fumarolic emissions. Nonetheless, huge amounts of deep-seated gases enter the atmosphere as diffuse emissions from the soil surface (Valenza, 1993; Giammanco et al., 1995a,b; Aiuppa et al., 2004; Giammanco et al., 2007; Camarda et al., 2012). Geochemical investigations of diffuse degassing and fumarolic emissions have been used for decades for volcano surveillance, especially at quiescent volcanoes during their transition toward eruptive conditions (Badalamenti et al., 1994; Barberi

\footnotetext{
* Corresponding author.

E-mail address: robertomr.dimartino@gmail.com (R.M.R. Di Martino).
}

and Carapezza, 1994; Giammanco et al., 1995a,b; Giammanco et al., 1996; Aiuppa et al., 2007).

Different components of volcanic gases (e.g., helium, radon, carbon dioxide, and molecular hydrogen) have been investigated, and their relationships with the reservoirs have been used to identify sensitive tracers of specific geochemical processes. The monitoring of both $\mathrm{CO}_{2}$ flux and $\mathrm{H}_{2}$ concentration in active volcanic areas helps to improve the understanding of the processes linking the surface gas emissions, the chemistry of the gases released from magmas, and the volcanic activity.

Among the routine techniques, $\mathrm{CO}_{2}$ flux measurement is one of the most promising tools for monitoring volcanic activity because $\mathrm{CO}_{2}$ is the main volatile component behind $\mathrm{H}_{2} \mathrm{O}$ in silicate magmas, attaining saturation at the mantle to deep crustal level (Kamenetsky et al., 2007). Therefore, large amounts of $\mathrm{CO}_{2}$ are released early upon magma ascent, before or during eruptions.

According to Allard et al. (1991), the $\mathrm{CO}_{2}$ released from the upper flank of Mt Etna during a high level of volcanic activity equals the amount released from the central conduits. Moreover, the variations of the $\mathrm{CO}_{2}$ flux from fumaroles of the summit areas preceded the increases of volcanic activity (Giammanco et al., 1998).

The $\mathrm{H}_{2}$ concentration has provided indications concerning the oxygen fugacity $\left(f_{\mathrm{O}_{2}}\right)$ of magmatic gases. The oxygen fugacity of the magmatic gases is low (Heald et al., 1963; Sato and Moore, 1973; Gerlach, 1983; Benhamou et al., 1988) but its value changes over a wide range $\left(10^{-16}-10^{-8}\right.$ bar) and affects the redox state of the multivalent elements (Fudali, 1965; Sato, 1978; Carmichael and Ghiorso, 1986; Moretti and Papale, 2004). If the time required by gases to arrive at the Earth surface is shorter than that required by homogeneous reactions to equilibrate the gas composition, the oxygen fugacity of the volcanic 
gases reflects the heterogeneous gas-melt reactions occurring in the magma reservoir (Candela, 1986; Giggenbach, 1987). Therefore, the oxygen fugacity of magmatic gases has a key role in order to understand the volcanic activity. However, the direct measurements of $f_{\mathrm{O}_{2}}$ have disadvantages owing to the low partial pressure of free $\mathrm{O}_{2}$ in magmatic gases and for the error arising from the atmospheric contamination of the volcanic gases near the Earth surface. The magmatic $f_{\mathrm{H}_{2}}$ is related to $f_{\mathrm{O}_{2}}$ by the water dissociation reaction at high temperature (Giggenbach, 1987), therefore the continuous monitoring of $\mathrm{H}_{2}$ concentration provides indications concerning the changes in oxygen fugacity of the volcanic gases and that of the redox equilibriums of the magma (Aiuppa et al., 2011). Moreover, the average magmatic $f_{\mathrm{H}_{2}}$ is six orders of magnitude greater than $f_{\mathrm{O}_{2}}$ and less affected by atmospheric contamination because the $\mathrm{H}_{2}$ concentration in the air is low and constant (0.5 ppm vol).

Transient peaks in the $\mathrm{H}_{2}$ concentration (referred to as " $\mathrm{H}_{2}$ pulses" here) have been documented before the onset of volcanic eruptions (Oskarsson, 1984) or immediately before major changes in the eruptive activity (Giammanco et al., 1998). Several efforts have been made to improve the techniques and upgrade the system for monitoring the volcanic activity.

In this paper we report the use of a hydrogen fuel cell as an $\mathrm{H}_{2}$ specific sensor. The fuel cell (Rew Power@ fuel cell - model 023) was used in an automated device to measure and record the $\mathrm{H}_{2}$ concentration in fumarole gases. The device was also equipped with an IR spectrophotometer in order to simultaneously measure the soil $\mathrm{CO}_{2}$ flux emitted in the same area. The device was installed on the ground near a low-temperature fumarole at Mt Etna (Belvedere (BLV)) (Fig. 1), and the results of the $\mathrm{H}_{2}$ concentration and $\mathrm{CO}_{2}$ flux monitoring during 2009 and 2010 are presented herein. The acquired data were also investigated relative to the eruptive activity of Mt Etna during the same period.

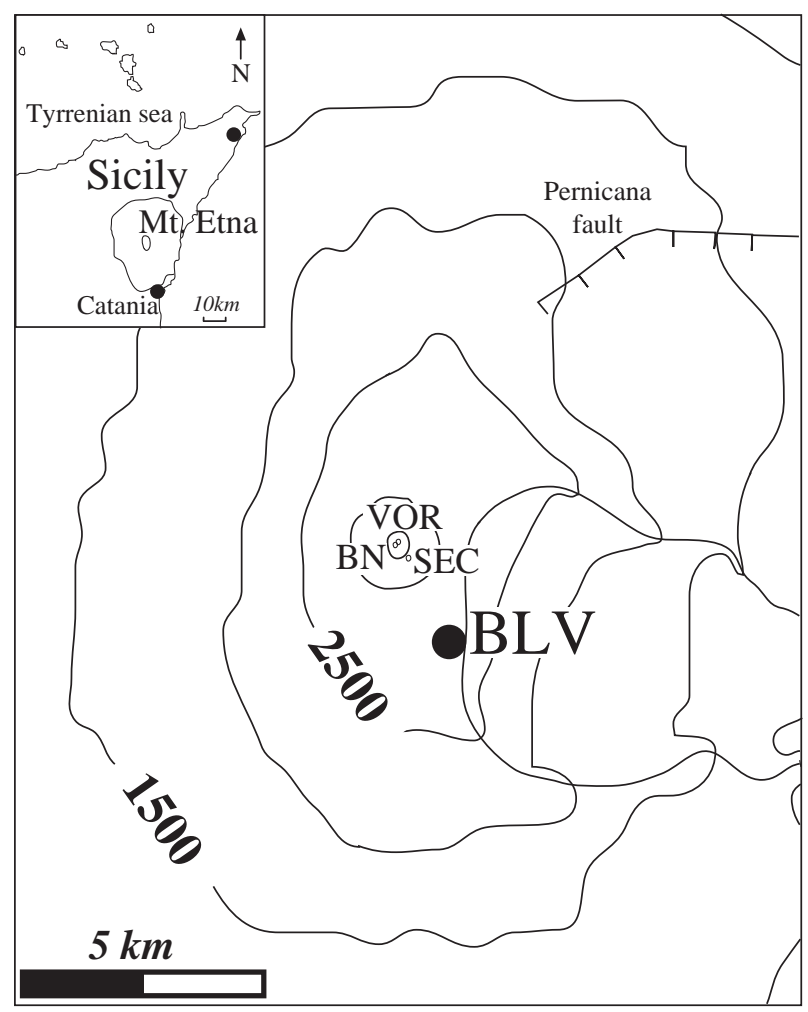

Fig. 1. Map of the summit area of Mt Etna volcano indicating the site of measurement (BLV) and the summit craters (SEC, South East Crater; BN, Bocca Nuova; VOR, Voragine).

\section{Materials and methods}

\subsection{Fuel cell system}

Hydrogen fuel cells are electrochemical devices used to produce electric current using hydrogen gas (Zhdanov, 2007). The basic structure of a hydrogen fuel cell comprises two electrodes separated by a hydrated Nafion ${ }^{\circledR}$ membrane and connected in series with an electric circuit containing a resistor (Mehta and Cooper, 2003). The working process consists of two matched platinum (Pt)-catalyzed redox halfreactions taking place at the cell electrodes: the $\mathrm{H}_{2}$ oxidation reaction occurs at the anode, while the molecular oxygen $\left(\mathrm{O}_{2}\right)$ reduction reaction takes place on the cathode side of the cell. The Pt catalyst enhances the hydrogen oxidation rate on the anode electrode according to the following half-cell reaction:

$\mathrm{H}_{2} \rightarrow 2 \mathrm{H}^{+}+2 \mathrm{e}^{-}$

The hydrated Nafion ${ }^{\circledR}$ membrane, acting as solid electrolyte, allows the protons to pass toward the cathode. Protons are linked to the $\mathrm{H}_{2} \mathrm{O}$ molecules and move as $\mathrm{H}_{3} \mathrm{O}^{+}$ions through the solid electrolyte membrane. The electrons flow through the resistance in the external circuit.

On the cathode side of the cell, Pt catalyzes the $\mathrm{O}_{2}$ reduction according to

$\frac{1}{2} \mathrm{O}_{2}+2 \mathrm{H}^{+}+2 \mathrm{e}^{-} \rightarrow 2 \mathrm{H}_{2} \mathrm{O}$

Therefore, the overall redox process occurring within the hydrogen fuel cell is the inverse water electrolysis reaction:

$\mathrm{H}_{2}+\mathrm{O}_{2} \rightarrow \mathrm{H}_{2} \mathrm{O}$.

The electric current flowing through the external circuit is proportional to the amount of $\mathrm{H}_{2}$ that has been oxidized at the anode, and so its measurement reveals the $\mathrm{H}_{2}$ concentration within the gas entering the fuel cell. In order to use the hydrogen fuel cell as an $\mathrm{H}_{2}$ sensor, the anode is the sensing electrode and the cathode is the reference electrode. The electric current flowing through the external circuit represents the signal to be measured, and this is achieved by measuring the voltage drop across the known load resistance.

\subsection{The $\mathrm{H}_{2}$ sensor}

Fig. 2 shows the main hydraulic and electronic components used in the laboratory to test the operation of the fuel cell (Rew Power@ fuel cell - model 023) as an $\mathrm{H}_{2}$-specific sensor. Standard $\mathrm{H}_{2}$ mixtures enter the anode of the cell at a known constant flux rate. The air entering the cathode passes through a water-filled bubbler, which keeps the moisture levels of both the electrode and membrane fairly constant, thereby optimizing the water management of the sensor.

Fig. 3a shows an example result of the fuel-cell characterization tests, which illustrates that the voltage rapidly increased (transient state) to a maximum value (steady state) a few seconds after the gas entered the sensor. The stationary signal value was proportional to the $\mathrm{H}_{2}$ concentration within the mixture.

Several tests were performed in order to determine the repeatability of the measurements, and the resolution, accuracy, and response time of the $\mathrm{H}_{2}$ sensor. Preliminary tests indicated that a 500 -ohm resistor provided a sensor signal with the optimal resolution, response time, and linearity.

Fig. 3b summarizes six repeated tests performed with an $\mathrm{H}_{2}$ (100 ppm vol)-air mixture. The sensor was flushed with air for several minutes between subsequent tests in order to set the measurement baseline corresponding to the absence of $\mathrm{H}_{2}$. In these tests the largest 


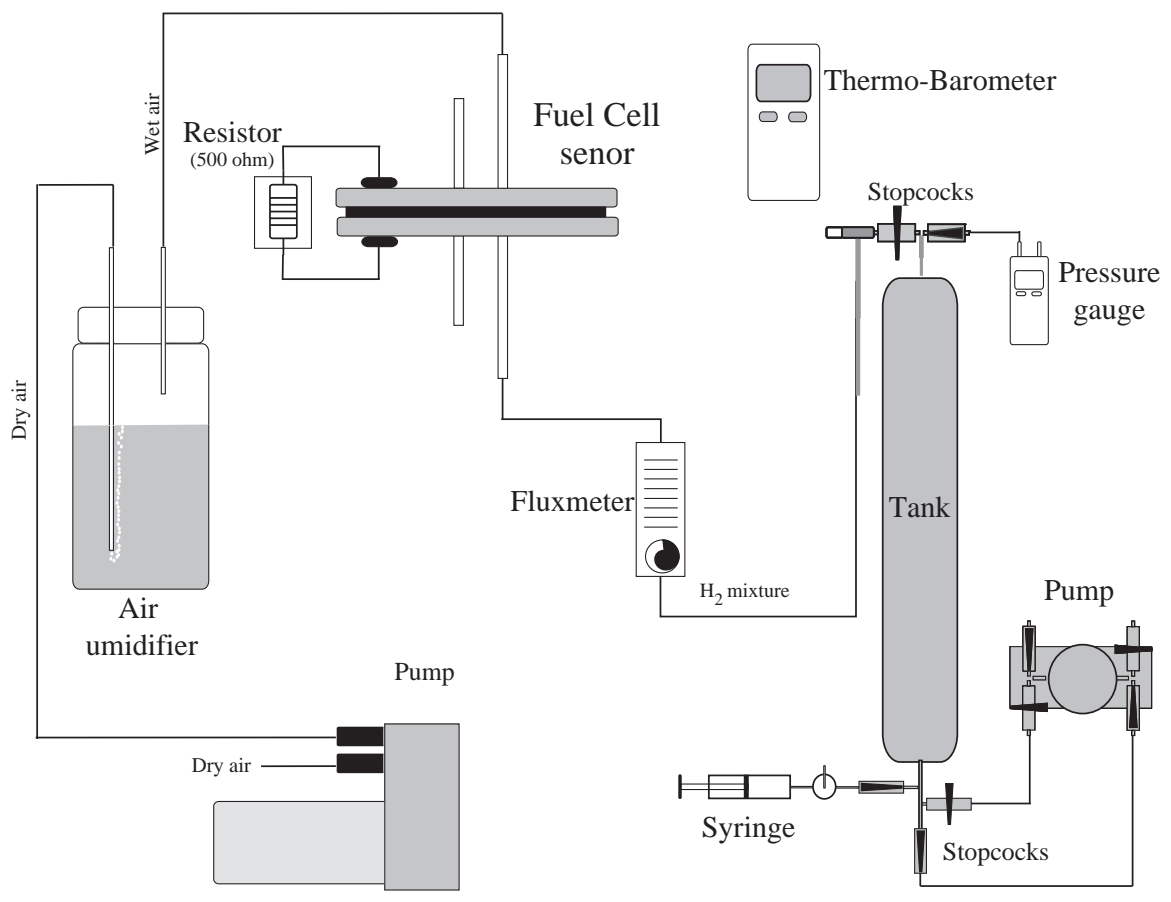

Fig. 2. Laboratory equipment used to test the operation of the Rew Power@ fuel cell as $\mathrm{H}_{2}$-specific sensor.

deviation was $1 \mathrm{mV}$ from an average reading of $16 \mathrm{mV}$, suggesting that the reproducibility error was around 3\%.

Fig. $3 \mathrm{c}$ shows the times required to reach $90 \%$ of the final signal (T90) as a function of the $\mathrm{H}_{2}$ concentration. The figure shows that T90 was slightly dependent from the $\mathrm{H}_{2}$ concentration, but it was lower than $300 \mathrm{~s}$ for the range of $\mathrm{H}_{2}$ concentration tested. A linear relationship was obtained between the sensor signal and the $\mathrm{H}_{2}$ concentration over the full range of concentrations investigated, with a sensitivity of $0.2 \mathrm{mV}(\mathrm{ppm} \mathrm{vol})^{-1}$ of $\mathrm{H}_{2}$ (Fig. 3d).

In order to investigate the cross-sensitivity effects produced by the changes in the environmental conditions, the signal-concentration tests were repeated for the atmospheric pressure differing by a maximum on
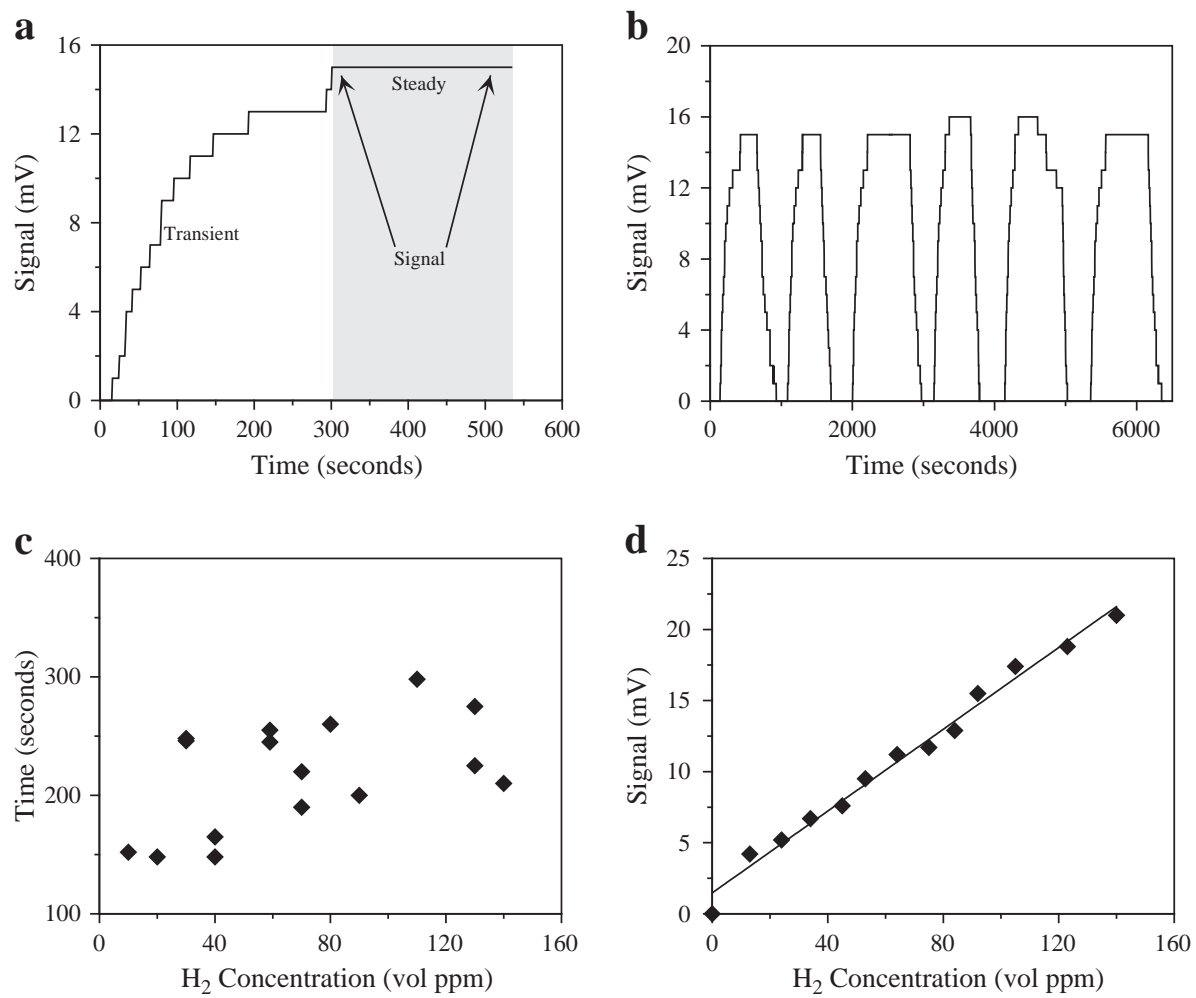

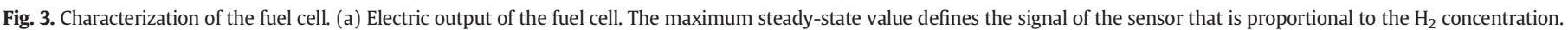
(b) Six subsequent repetitions of the signal measurement tests. (c) $\mathrm{T} 90 \mathrm{vs}_{2}$ concentration. (d) Sensor signal vs $\mathrm{H}_{2}$ concentration. 
the order of tenths of mbar, while the laboratory temperature was almost unchanged (Table 1). The results indicate that the measured signal values differed by less than a few hundredths of $\mathrm{mV}$ between the first two tests, and by about $10 \%$ five days later. The measurements showed a standard deviation of about $10 \mathrm{mV}$, corresponding to the $\mathrm{H}_{2}$ concentration sensor having an accuracy of $\pm 5 \mathrm{ppm}$ vol.

The tests were repeated for flux rates of the standard gases entering the anode of the sensor of $0.25-0.51 \mathrm{~min}^{-1}$, which correspond to the anticipated operational conditions in field applications; this resulted in no changes in the measured signal values (Table 2).

\subsection{Influences of the $\mathrm{H}_{2}$ dilution matrix}

In order to determine the reliability of the $\mathrm{H}_{2}$ concentration measurements in volcanic areas, several tests were performed by using $\mathrm{CO}_{2}$ as a dominant gas component, because $\mathrm{CO}_{2}$ is one of the main components of fumarolic emissions. Fig. 4a compares the results of tests performed with the $\mathrm{H}_{2}-\mathrm{CO}_{2}$ mixtures with those of the six tests performed with the $\mathrm{H}_{2}-\mathrm{N}_{2}$ standard. In each test the $\mathrm{H}_{2}$ concentration ranged between $0.5 \mathrm{ppm}$ vol (air) and $200 \mathrm{ppm}$ vol. The data show that the steady-state sensor signal increased by about $10 \%$ for the $\mathrm{CO}_{2}$ matrix. Moreover, the $\mathrm{CO}_{2}$ detector could be indirectly used to evaluate the $\mathrm{CO}_{2}$ amounts in field measurements.

\subsection{Influences of other reducing gas species}

The chemical composition of fumarole gases includes $\mathrm{CO}_{2}$ as the dominant component together with several other species such as $\mathrm{CH}_{4}, \mathrm{CO}$, and $\mathrm{H}_{2} \mathrm{~S}$ that show reducing capacities. Several tests were performed to verify the cross-sensitivity effects of the reducing components on $\mathrm{H}_{2}$ detection. Fig. $4 \mathrm{~b}$ shows the results of the tests performed by using pure $\mathrm{CH}_{4}\left(\mathrm{CH}_{4}=99.99\right.$ vol.\%), a $\mathrm{CH}_{4}$-air mixture $\left(\mathrm{CH}_{4}=100 \mathrm{ppm}\right.$ vol), and an $\mathrm{H}_{2}$-air mixture $\left(\mathrm{H}_{2}=100 \mathrm{ppm}\right.$ vol $)$. The results suggest that the cross-sensitivity effect produced by the $\mathrm{CH}_{4}$ amounted to $1 \mathrm{mV}$ and was independent of its concentration. The absence of cross-sensitivity with $\mathrm{CH}_{4}$ was probably due to the slow kinetics of its oxidation reaction at low temperatures.

Fig. 4c shows the results of the tests performed with mixtures containing both $\mathrm{H}_{2}$ and $\mathrm{CO}$ reducing species, with the $\mathrm{CO} / \mathrm{H}_{2}$ concentration ratio set to 1 and to 0.02 . The results show that CO induced a $20 \%$ error in the $\mathrm{H}_{2}$ measurements when it is present in the same concentration as $\mathrm{H}_{2}$. By contrast, when the $\mathrm{CO} / \mathrm{H}_{2}$ ratio is 0.02 , very small differences were observed between the signal obtained with and without the presence of $\mathrm{CO}$ in the gas mixture. Therefore, based on the results of our tests and assuming a linear behavior of the cross sensitivity of $\mathrm{CO}$, we suggest that 0.25 is the $\mathrm{CO} / \mathrm{H}_{2}$ ratio affecting the $\mathrm{H}_{2}$ measurements in the order of $5 \%$.

Sulfur gases are among the major components of volcanic emissions. The cross-sensitivity effect of $\mathrm{H}_{2} \mathrm{~S}$ has been evaluated because it is the main sulfur species emitted from low-temperature fumaroles. Fig. $4 \mathrm{~d}$ shows the results of the five tests performed with the $\mathrm{H}_{2} \mathrm{~S}$ concentration

Table 1

Set of cross-sensitivity tests performed for different atmospheric pressure conditions.

\begin{tabular}{lccc}
\hline $\begin{array}{l}\mathrm{H}_{2} \text { Concentration } \\
(\mathrm{ppm} \mathrm{vol})\end{array}$ & $\begin{array}{l}\text { Signal first test } \\
(\mathrm{mV})\end{array}$ & $\begin{array}{l}\text { Signal 1-day after } \\
(\mathrm{mV})\end{array}$ & $\begin{array}{l}\text { Signal 5-days after } \\
(\mathrm{mV})\end{array}$ \\
\hline 13 & 4.1 & 4.0 & 4.4 \\
24 & 5.0 & 5.4 & 6.1 \\
34 & 6.7 & 6.5 & 7.1 \\
45 & 7.6 & 7.5 & 10.0 \\
53 & 9.5 & 9.2 & 10.2 \\
64 & 11.2 & 11.4 & 13.0 \\
75 & 11.7 & 11.8 & 13.5 \\
84 & 13.0 & 13.0 & 16.1 \\
92 & 15.5 & 15.5 & 16.6 \\
105 & 17.1 & 17.2 & 17.6 \\
\hline
\end{tabular}

Table 2

Set of cross-sensitivity tests performed for different flux rates of the gas at the cell anode.

\begin{tabular}{lcc}
\hline $\begin{array}{l}\mathrm{H}_{2} \text { Concentration } \\
(\mathrm{ppm} \text { vol })\end{array}$ & $\begin{array}{l}\text { Signal }- \text { flux } 0.25 \mathrm{l} \mathrm{min}^{-1} \\
(\mathrm{mV})\end{array}$ & $\begin{array}{l}\text { Signal }- \text { flux } 0.51 \mathrm{~min}^{-1} \\
(\mathrm{mV})\end{array}$ \\
\hline 13 & 4.1 & 4.1 \\
24 & 5.0 & 5.0 \\
34 & 6.0 & 6.1 \\
45 & 7.2 & 7.3 \\
53 & 9.0 & 9.0 \\
64 & 11.4 & 11.5 \\
75 & 11.8 & 11.8 \\
84 & 13.0 & 13.0 \\
92 & 15.5 & 15.4 \\
105 & 17.1 & 17.2 \\
123 & 18.8 & 18.8 \\
\hline
\end{tabular}

up to $50 \mathrm{ppm}$ vol, and that of $\mathrm{H}_{2}$ ranging from $0.5 \mathrm{ppm}$ vol (air only) to $110 \mathrm{ppm}$ vol. The sensitivity of the sensor to $\mathrm{H}_{2} \mathrm{~S}\left(0.8 \mathrm{mV}(\mathrm{ppm} \mathrm{vol})^{-1}\right)$ was 4 times higher than its sensitivity to $\mathrm{H}_{2}\left(0.2 \mathrm{mV}(\mathrm{ppm} \text { vol })^{-1}\right)$, as predicted by the oxidation reaction of one mole of $\mathrm{H}_{2} \mathrm{~S}$ :

$\mathrm{H}_{2} \mathrm{~S}+4 \mathrm{H}_{2} \mathrm{O} \rightarrow \mathrm{SO}_{4}^{2-}+8 \mathrm{e}^{-}+10 \mathrm{H}^{+}$.

The Eq. (4) involves eight electrons, which is 4 times the number of electrons involved in the oxidation of one mole of $\mathrm{H}_{2}$. In field applications, the large cross-sensitivity produced by $\mathrm{H}_{2} \mathrm{~S}$ on $\mathrm{H}_{2}$ measurements will be removed by sampling the gases through an $\mathrm{H}_{2} \mathrm{~S}$ chemical trap between the probe and the sensor (e.g., a lead acetate trap, $\left.\mathrm{Pb}\left(\mathrm{CH}_{3} \mathrm{COO}\right)_{2}\right)$.

Both the validity of the sampling method and the performance of the $\mathrm{H}_{2}$ sensor were first tested at Solfatara di Pozzuoli (Phlegraean Fields, Italy). The gases were collected by inserting a probe into the soil up to a depth of $50 \mathrm{~cm}$. The $\mathrm{H}_{2} \mathrm{~S}$ concentration of the samples collected without an $\mathrm{H}_{2} \mathrm{~S}$ trap ranged between 1600 and 2000 ppm vol, while the $\mathrm{H}_{2} \mathrm{~S}$ concentrations measured for the samples collected with an $\mathrm{H}_{2} \mathrm{~S}$ trap ranged between 4 and $6 \mathrm{ppm}$ vol, thereby providing strong evidence of the good performance of the $\mathrm{H}_{2} \mathrm{~S}$ trap. The $\mathrm{H}_{2}$ concentrations measured with the fuel cell sensor (Table 3 ) were on the same order of magnitude as the concentrations measured by chromatographic techniques for different gas samples collected from the same sampling sites (Table 4). This agreement demonstrates the good performance of the $\mathrm{H}_{2}$ sensor, and provides further evidence that the fuel cell can act as an $\mathrm{H}_{2}$-specific sensor.

\subsection{The $\mathrm{H}_{2}-\mathrm{CO}_{2}$ device and measurement method}

The $\mathrm{H}_{2}-\mathrm{CO}_{2}$ system integrates the hydrogen fuel cell sensor (Rew Power@ fuel cell - model 023) and the IR spectrophotometer that provide measurements of the $\mathrm{H}_{2}$ concentration and $\mathrm{CO}_{2}$ flux, respectively. The IR spectrophotometer can measure the $\mathrm{CO}_{2}$ concentration over the range $0-100 \mathrm{vol} \%$. The $\mathrm{CO}_{2}$ sensitivity was of $1000 \mathrm{ppm}$ vol, while the accuracy was $\pm 2 \%$ of the full range. The $\mathrm{CO}_{2}$ flux was measured according to the dynamic concentration method (Gurrieri and Valenza, 1988; Camarda et al., 2006), which consists of measuring the $\mathrm{CO}_{2}$ concentration in a mixture of air and soil gas that has been sampled with a specially designed probe inserted into the soil at a depth of $50 \mathrm{~cm}$ (Camarda et al., 2006).

The $\mathrm{H}_{2}$ concentration was measured using the fuel cell described above. During each measurement, the fumarole gas was sampled at a constant rate of $0.51 \mathrm{~min}^{-1}$ for $7 \mathrm{~min}$ through a tailor-made probe inserted into the soil at a depth of $50 \mathrm{~cm}$ (Fig. 5). The lower part of the probe has some openings through which the gas can be drained and sampled. Each measurement cycle consists of four consecutive readings of the $\mathrm{H}_{2}$ concentration. The first reading of the $\mathrm{H}_{2}$ sensor occurs $60 \mathrm{~s}$ after pump activation, while the next three readings at $90 \mathrm{~s}$ interval from each other in order to reproduce the response curve (Fig. 3a) and, therefore, to check the goodness of the measurements. 

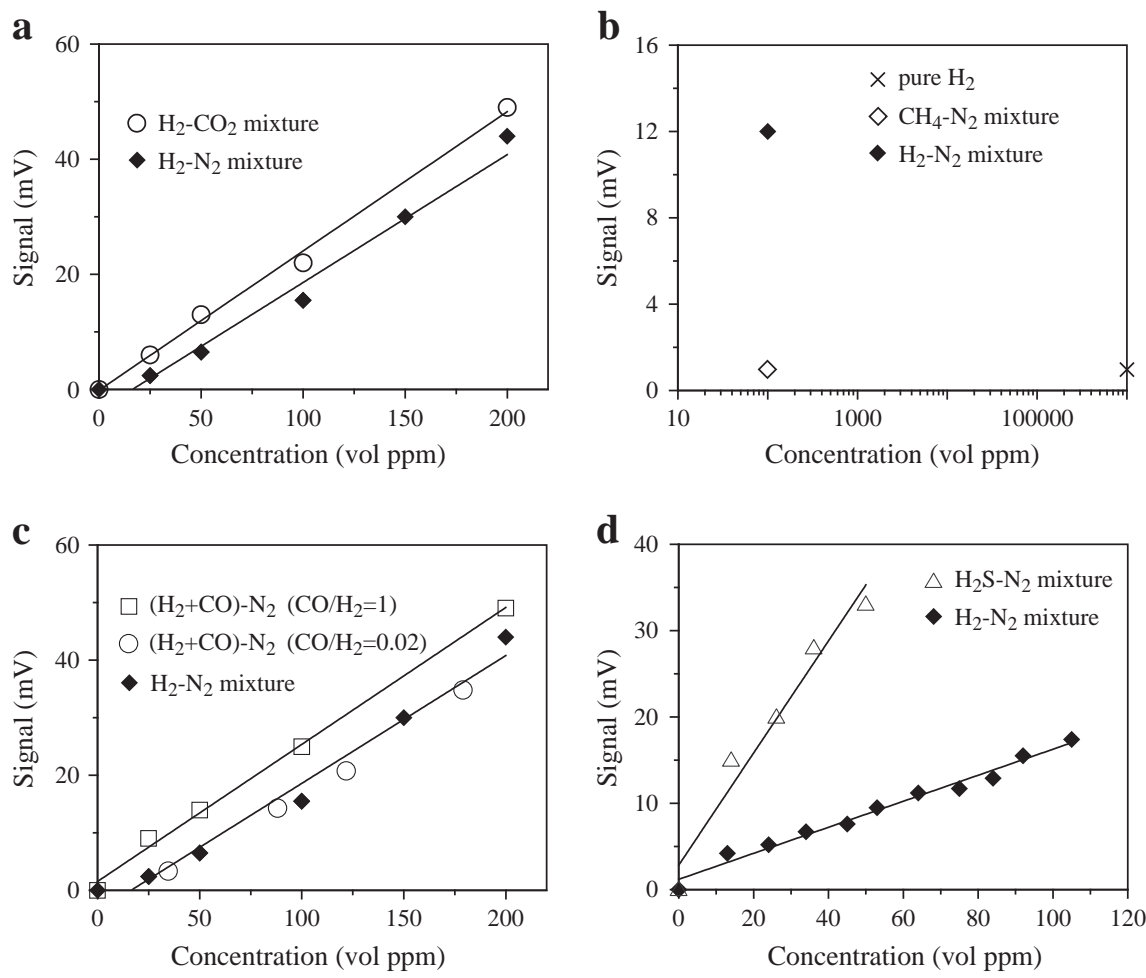

Fig. 4. Cross-sensitivity effect of the sensor used for measuring the $\mathrm{H}_{2}$ concentration. (a) Effect of the $\mathrm{CO}_{2}$ matrix; (b) effect of the $\mathrm{CH}_{4}$; (c) effect of the $\mathrm{CO}$; (d) effect of the $\mathrm{H}_{2} \mathrm{~S}$.

We verified for the entire data record that the subsequent acquisitions were arranged in agreement with the response curve ensuring the proper working of the sensor.

In order to prevent the cross-sensitivity and the detrimental effects produced by $\mathrm{H}_{2} \mathrm{~S}$ on the Pt-electrodes, a lead acetate trap was placed between the probe and the $\mathrm{H}_{2}$ sensor. More technical aspects of the $\mathrm{H}_{2}-$ $\mathrm{CO}_{2}$ device used in the field were reported and described in the Appendix A.

\subsection{Measurement site}

The above-described tailor-made device for continuously monitoring the $\mathrm{H}_{2}$ concentration and $\mathrm{CO}_{2}$ flux was installed on Mt Etna. This is a $3300 \mathrm{~m}$ high stratovolcano covering more than $1200 \mathrm{~km}^{2}$ on the eastern side of Sicily (Italy). Very intense $\mathrm{CO}_{2}$ emissions take place from the summit craters and along the active structures (D'Alessandro et al., 1997; Giammanco et al., 1997; Aiuppa et al., 2004; Giammanco et al., 2010) of the Etna's flanks (Allard et al., 1991; Gerlach, 1991). The automated device was installed at BLV (Fig. 1) on the southeastern flank of the volcano, about $2 \mathrm{~km}$ away from the southeast crater (SEC) at an altitude of about $2700 \mathrm{~m}$ a.s.l. This site is characterized by a low-temperature fumarole field $\left(\mathrm{T}<100{ }^{\circ} \mathrm{C}\right)$ that formed after the $1991-1993$ eruption, where the eruptive fissure crossed the edge of the Valle del Bove (Pecoraino and Giammanco, 2005).
The $\mathrm{H}_{2}-\mathrm{CO}_{2}$ continuous monitoring started on July 22nd, 2009 some days after the end of the 2008-09 eruption (which ended on July 6th) and lasted until November 1st, 2010. There are some gaps in the data acquired during winter due to abundant snow preventing the maintenance of the experimental $\mathrm{H}_{2}-\mathrm{CO}_{2}$ system.

A few gas samples were occasionally collected during the monitoring period. The samples were collected as "dry gas" in glass sample holder and analyzed by a chromatographic technique, using a gas chromatograph Claurus 500 from Perkin Elmer equipped with column Packed 60/80 Carboxen 1000, $4.5 \mathrm{~m}$, hot wire and flame ionization detectors. Argon was the gas carrier. Furthermore we measured in situ the soil temperature at $30 \mathrm{~cm}$ depth by using a K-type thermocouple (measurement accuracy $\pm 0.5^{\circ} \mathrm{C}$ ) and the $\mathrm{H}_{2} \mathrm{~S}$ concentration by using a $\mathrm{H}_{2} \mathrm{~S}$ specific sensor (City Technology Limited mod. EZT3H CiTiceL ${ }^{\circledR}$ range $0-100$ ppm vol.).

As shown in Table 5 the sampled gases are composed essentially of $\mathrm{O}_{2}, \mathrm{~N}_{2}$ and $\mathrm{CO}_{2}$ with a few ppm vol of He and $\mathrm{H}_{2}$. They are obviously a mixing between air and the fumarolic gas coming out from the fractures that feed the BLV fumarolic field. The soil temperature values measured at a $30 \mathrm{~cm}$ depth at the measurement site were always lower than $80{ }^{\circ} \mathrm{C}$. The $\mathrm{H}_{2} \mathrm{~S}$ concentrations were lower than the detection limit of the $\mathrm{H}_{2} \mathrm{~S}$ specific sensor ( $0.2 \mathrm{ppm}$ vol.), with the exception of the May 2010 survey, when $2 \mathrm{ppm}$ vol of $\mathrm{H}_{2} \mathrm{~S}$ were measured. However, the lead acetate trap was placed anyway between the sampling probe and the $\mathrm{H}_{2}$ sensor of the automated device (Fig. 5).

Table 3

$\mathrm{H}_{2}$ concentration measured at Solfatara di Pozzuoli.

\begin{tabular}{lc}
\hline Site & Concentration $\left(\mathrm{H}_{2}\right.$-Sensor $)$ \\
\hline P1-a & 27 \\
P1-b & 48 \\
P1-c & 38 \\
P2-a & 328 \\
P2-b & 317 \\
\hline
\end{tabular}

Table 4

Chemical compositions of the gas samples collected at Solfatara di Pozzuoli.

\begin{tabular}{llclllll}
\hline Sample & $\mathrm{He} \mathrm{ppm}$ & $\mathrm{H}_{2} \mathrm{ppm}$ & $\mathrm{O}_{2} \%$ & $\mathrm{~N}_{2} \%$ & $\mathrm{CO} \mathrm{ppm}$ & $\mathrm{CH}_{4} \mathrm{ppm}$ & $\mathrm{CO}_{2} \%$ \\
\hline P1 & 8 & 27 & 3.50 & 18.01 & 1.3 & 50 & 78.02 \\
P2-1 & 9 & 308 & 3.48 & 13.96 & 1.9 & 86 & 82.65 \\
P2-2 & 8 & 273 & 5.53 & 21.98 & 3 & 79 & 72.74 \\
P2-3 & 8 & 273 & 4.26 & 17.23 & 1.1 & 66 & 78.70 \\
\hline
\end{tabular}




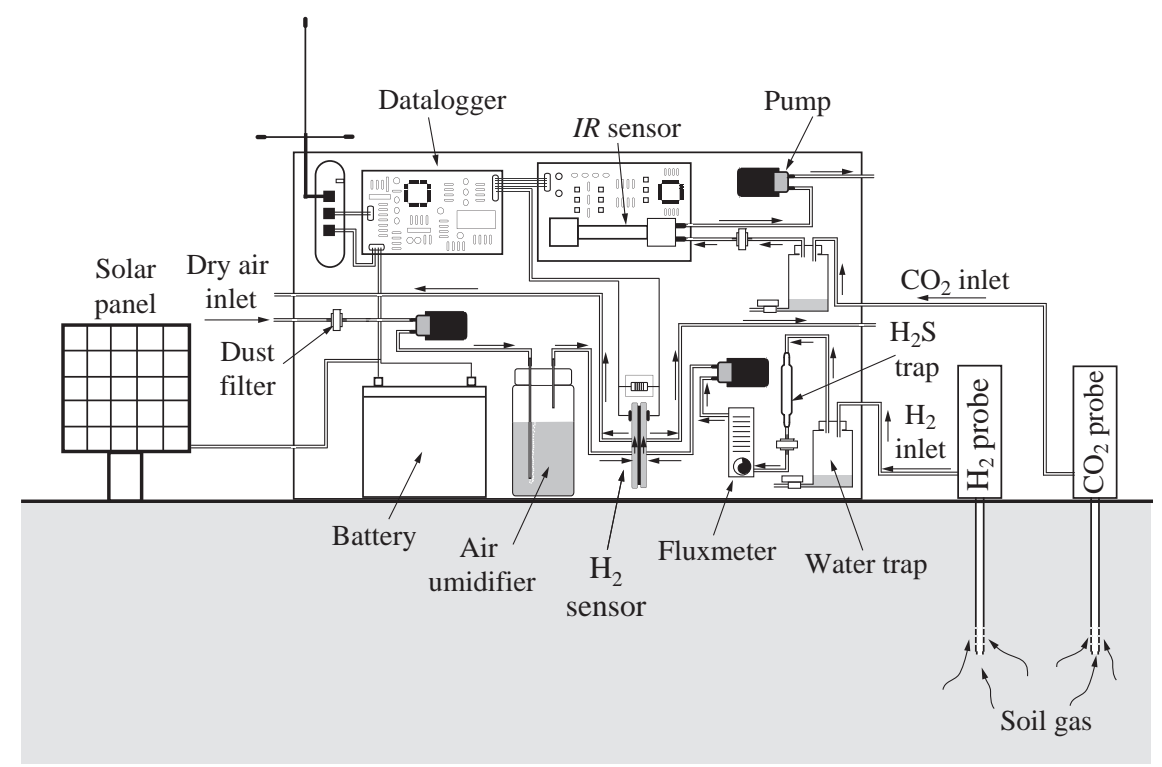

Fig. 5. Sketch of the device used for continuous measuring $\mathrm{H}_{2}$ concentration and soil $\mathrm{CO}_{2}$ flux on Mt Etna.

The overall aim of the continuous monitoring of $\mathrm{H}_{2}$ and $\mathrm{CO}_{2}$ at $\mathrm{BLV}$ was to investigate the changes of both the $\mathrm{H}_{2}$ concentration and the $\mathrm{CO}_{2}$ flux in order to provide insights into the shallow degassing dynamics of the volcanic system.

\section{Results}

The red line in Fig. 6 shows the $\mathrm{H}_{2}$ concentration measured at BLV since July 2009 to November 2010. These values show very wide variation from about $2 \mathrm{ppm}$ to $150 \mathrm{ppm}$ vol during the monitoring period. We used a normal probability plot (PP) to identify anomalous values of $\mathrm{H}_{2}$ concentration (Sinclair, 1974). This type of plot expresses on a probability scale the cumulative frequencies of the measured $\mathrm{H}_{2}$ concentrations. Data that are normally distributed will appear in such a plot as a straight line. Therefore, the presence of multiple straight lines, with different slopes indicates the presence of various populations of data with normal distributions. The probability plot showed in Fig. 7a indicates three main populations of $\mathrm{H}_{2}$ concentration that defined about $99 \%$ of all of the measurement data set above the detection limit of the sensor ( $5 \mathrm{ppm}$ vol): (i) about $1 \%$ of the complete data set was the population of the highest values (anomalous population) having $\mathrm{H}_{2}$ concentrations above $36 \mathrm{ppm}$ vol, (ii) about $78 \%$ of

Table 5

Chemical composition of the soil gas sampled at BLV. Analytical data are expressed as ppm $\operatorname{vol}\left(\mathrm{He}, \mathrm{H}_{2}, \mathrm{CH}_{4}, \mathrm{H}_{2} \mathrm{~S}\right)$ and \% vol $\left(\mathrm{CO}_{2}, \mathrm{~N}_{2}, \mathrm{O}_{2}\right)$. The last column reports the values of soil temperature measured at $30 \mathrm{~cm}$ depth.

\begin{tabular}{lllllllll}
\hline Date & $\mathrm{He}$ & $\mathrm{H}_{2}$ & $\mathrm{O}_{2}$ & $\mathrm{~N}_{2}$ & $\mathrm{CH}_{4}$ & $\mathrm{CO}_{2}$ & $\mathrm{H}_{2} \mathrm{~S}$ & $\mathrm{~T}{ }^{\circ} \mathrm{C}(30 \mathrm{~cm}$ depth $)$ \\
\hline $07-22-2009$ & 6.5 & 16 & 15.39 & 72.39 & 9 & 10.43 & b.d.l. & 76.1 \\
$07-22-2009$ & 7 & 12 & 15.38 & 72.62 & 9 & 11.47 & b.d.l. & 76.6 \\
$09-10-2009$ & 4.4 & 30 & 16.11 & 72.19 & 12 & 11.89 & b.d.l. & 75.4 \\
$09-10-2009$ & 5 & 26 & 15.83 & 71.67 & 12 & 11.82 & b.d.l. & 75.3 \\
$09-10-2009$ & 7 & 30 & 15.86 & 71.73 & 12 & 11.90 & b.d.l. & 75.8 \\
$10-27-2009$ & 6 & 15 & 16.18 & 72.32 & 8 & 10.77 & b.d.l. & 79.2 \\
$10-27-2009$ & 8 & 14 & 15.82 & 72.94 & 8 & 10.63 & b.d.l. & 79.4 \\
$05-25-2010$ & 6 & 20 & 15.48 & 70.94 & 8 & 13.42 & 2 & 78.7 \\
$05-25-2010$ & 7 & 22 & 15.39 & 70.79 & 9 & 13.57 & 2 & 79.2 \\
$07-14-2010$ & 7 & 18 & 15.32 & 71.15 & 8 & 13.22 & b.d.l. & 83.3 \\
$07-14-2010$ & 5 & 15 & 15.48 & 71.22 & 8 & 13.03 & b.d.l. & 83.2 \\
$09-01-2010$ & 8 & 18 & 15.25 & 69.89 & 6 & 14.63 & b.d.l. & 78.3 \\
$09-01-2010$ & 8 & 17 & 15.16 & 70.01 & 6 & 14.79 & b.d.l. & 78.8 \\
$09-22-2010$ & 8 & 15 & 15.67 & 71.82 & 9 & 11.43 & b.d.l. & 76.3 \\
$09-22-2010$ & 7 & 12 & 15.64 & 71.86 & 9 & 11.61 & b.d.l. & 75.9 \\
\hline
\end{tabular}

the measurements represented the background population with the average value of $15 \mathrm{ppm}$ vol, and (iii) about $21 \%$ of the measurements had intermediate values between the anomalous and background populations. According to this distribution, the anomalous $\mathrm{H}_{2}$ emission mainly occurred during the second half of August 2010 (Fig. 6). As for the $\mathrm{H}_{2}$ concentrations, the soil $\mathrm{CO}_{2}$ flux (black line in Fig. 6) shows wide variation during the monitoring period, ranging from 800 up to about $1700 \mathrm{~g} \mathrm{~m}^{-2}$ day $^{-1}$. Also for the $\mathrm{CO}_{2}$ flux, the probability plot (Fig. 7b) shows the presence of three main flux populations: (i) about the $55 \%$ of the data set was the background population with an average value of $725 \mathrm{~g} \mathrm{~m}^{-2}$ day $^{-1}$, (ii) about $35 \%$ of the measurements was the anomalous population with flux values higher than $800 \mathrm{~g} \mathrm{~m}^{-2}$ day $^{-1}$, and (iii) the $10 \%$ of the measurements exhibited intermediate flux values. According to this distribution, there were anomalous levels of $\mathrm{CO}_{2}$ degassing during 2009, after the end of the 2008-2009 eruption (Fig. 6). On the other hand, noticeable variations were observed during 2010. The increasing trend from the end of May 2010 shifted the $\mathrm{CO}_{2}$ flux from background to anomalous values. This anomaly persisted from August to September 2010, after which the $\mathrm{CO}_{2}$ flux came back to the background values.

Fig. 8 shows a correlation diagram of the $\mathrm{H}_{2}$ concentration and $\mathrm{CO}_{2}$ flux data measured at BLV during 2009 and 2010. The dashed line indicates the threshold value of the anomalous $\mathrm{H}_{2}$ concentrations defined in the probability plot (Fig. 7). The trend line has a low correlation coefficient, suggesting that the two signals were independent. Therefore, a continuous monitoring of the $\mathrm{H}_{2}$ concentration and $\mathrm{CO}_{2}$ flux in fumaroles can provide distinct and complementary details on the evolution of the magmatic activity at Mt Etna.

\section{Discussion}

Since July to October 2009, the $\mathrm{H}_{2}$ concentration and the $\mathrm{CO}_{2}$ flux showed flat trends (Fig. 6). The average $\mathrm{CO}_{2}$ flux value of $1200 \mathrm{~g} \mathrm{~m}^{-2}$ day $^{-1}$ indicates the post-eruptive 2008-2009 level of the fumarolic $\mathrm{CO}_{2}$ flux at BLV. This trend has persisted since the end of the 2008-2009 eruption (which ended on July 6th, 2009) until October 2009, without a sign of a decrease. During the same period, the $\mathrm{H}_{2}$ concentration exhibited daily variations around the average background. The typical pattern of these daily variations (Fig. 9) indicates that the lowest and highest $\mathrm{H}_{2}$ concentrations were measured during the morning and night, respectively. Sato 

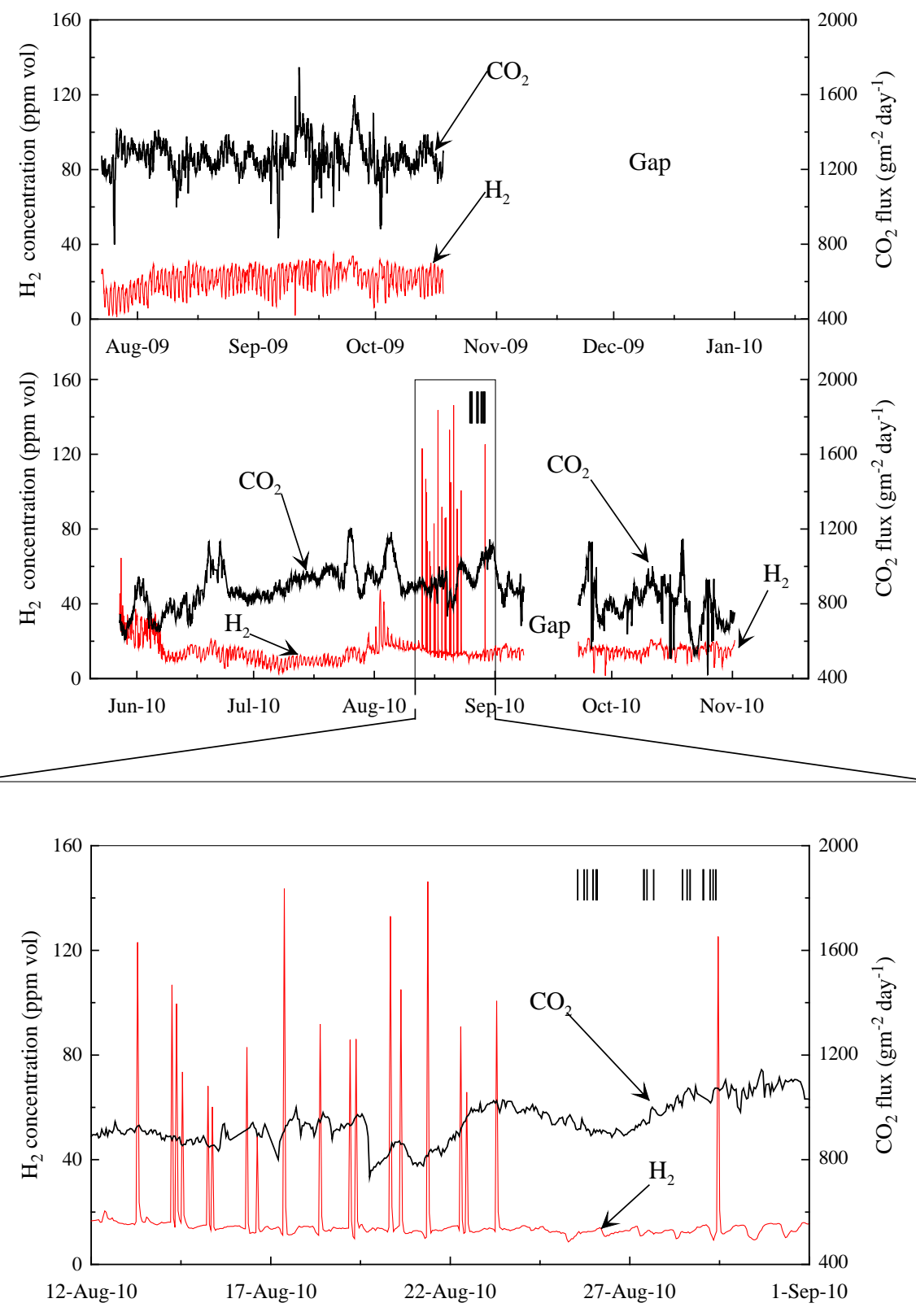

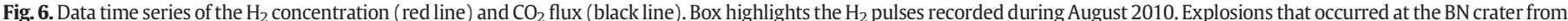
25 August 2010 are also indicated (vertical black line). (For interpretation of the references to color in this figure legend, the reader is referred to the web version of this article.).

and McGee (1982) described similar daily variations at Mount St. Helens, which were attributed to the reversal of orographic wind direction leading to variations of the plume-derived $\mathrm{H}_{2}$ content of the air being used as a gas reference for the detection device. In detail, during the morning reinforced anabatic wind allows wet sea breeze to reach the Etna's summit areas decreasing the $\mathrm{H}_{2}$ content of air inlet (in these conditions, BLV is upwind to the crater plumes). From late afternoon, the sea breeze effect is strongly reduced (Favalli et al., 2004; Zhu et al., 2008) and increases the $\mathrm{H}_{2}$ content of the air inlet, increasing the signal sensor (BLV results downwind to the crater plume). However, the daily average $\mathrm{H}_{2}$ concentration at Mt Etna (Fig. 10), by removing daily cyclic variations, showed a positive trend persisting since the end of July to September 2009, indicating an increase in the reducing capacity of the fumarole gases. The higher reducing capacity of the gas and the persisting level post eruption 2008-2009 of $\mathrm{CO}_{2}$ flux at BLV may indicate a hotter and gas-rich magma source that fed the fumarolic emissions. Also the $\mathrm{CO}_{2}$ flux record shows daily variations with smaller amplitude than $\mathrm{H}_{2}$ concentrations, since the IR spectrophotometer used in the devices has a very low sensibility ( $1000 \mathrm{ppm}$ vol). The daily variations of the $\mathrm{CO}_{2}$ concentration are due to diurnal variations of atmospheric temperature and pressure (Granieri et al., 2003; Carapezza et al., 2011).

The monitoring of $\mathrm{H}_{2}$ concentration and $\mathrm{CO}_{2}$ flux was interrupted during the winter of 2009 just some days before the formation of a new vent on the east slope of SEC with continuous degassing and some episodes of weak ash emissions. The monitoring station was reactivated in spring 2010. Since June 2010 the $\mathrm{CO}_{2}$ flux exhibited an increasing trend, reaching the relative maximum of $1000 \mathrm{~g} \mathrm{~m}^{-2}$ day $^{-1}$ at the beginning of September 2010. The $\mathrm{CO}_{2}$ flux values of the same order of magnitude of the post-eruptive 2008-2009 level may indicate a gas-rich source feeding the fumarolic emissions at BLV. In June and July 2010 the $\mathrm{H}_{2}$ concentration has exhibited background values of 

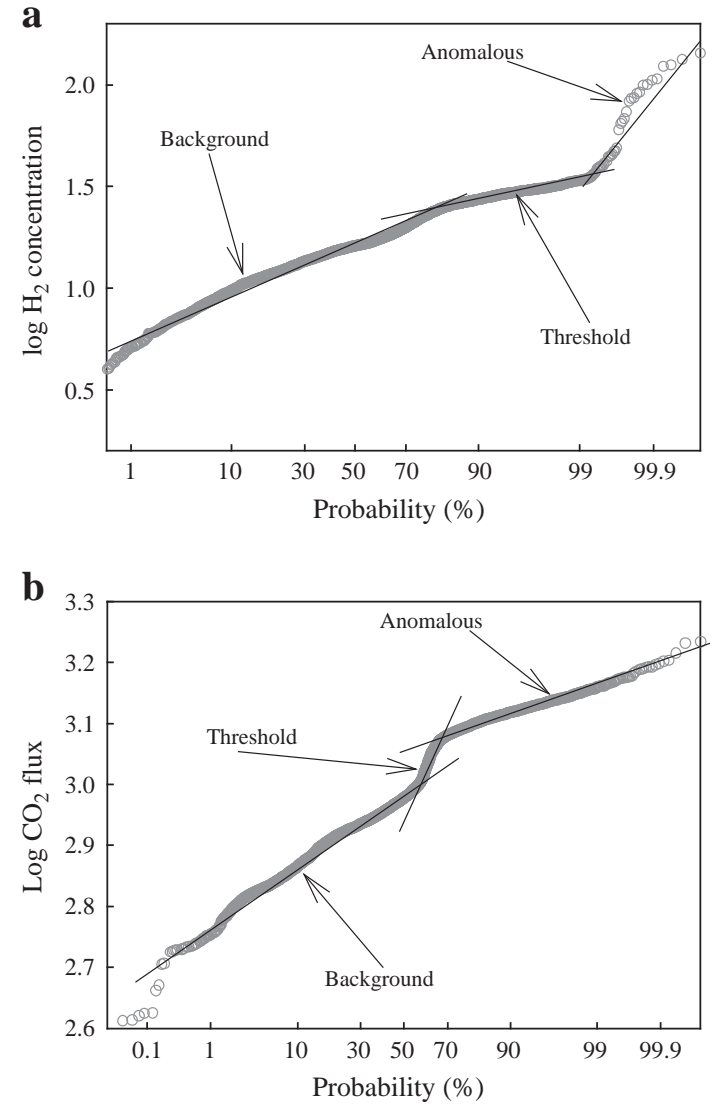

Fig. 7. Probability plots of the $\mathrm{H}_{2}$ concentration (a) and the $\mathrm{CO}_{2}$ flux (b).

a few ppm vol. Since July 31st, 2010 the daily average $\mathrm{H}_{2}$ concentration exhibited an increasing trend (Fig. 10), indicating a higher reducing capacity of the fumarole gases. During the same period other different geochemical data from INGV monitoring services exhibited significant variations that confirm the critical state of the volcano before August 25th. The soil radon measured in the summit area of Mt Etna showed significant variations just before and during the activity started on August 25th (INGV-CT; monitoring report available at http://www.pa.ingv.it). Also the $\mathrm{CO} / \mathrm{SO}_{2}$ ratio measured in the crater plume shows a strong decrease since the first of July 2010 and it reaches its minimum just some days before the BN explosive

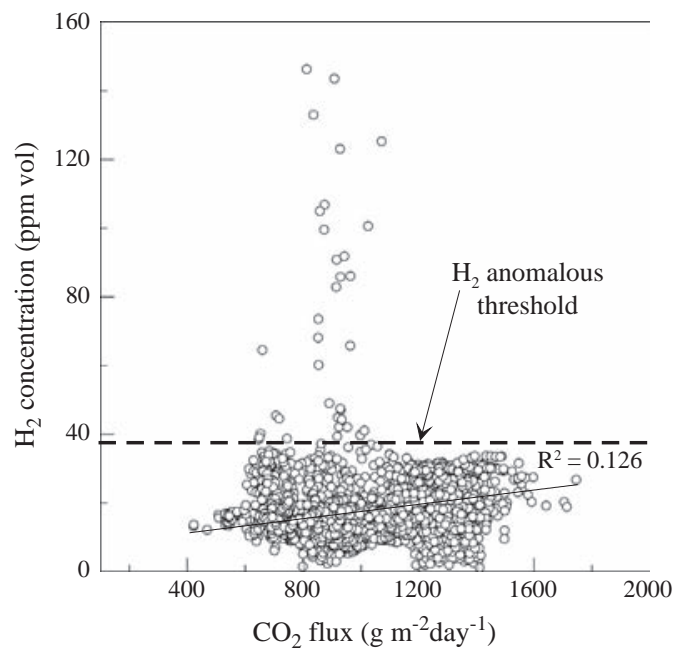

Fig. 8. Correlation diagram of $\mathrm{H}_{2}$ concentration vs $\mathrm{CO}_{2}$ flux. Dashed line indicates the threshold value of the anomalous $\mathrm{H}_{2}$ concentrations.

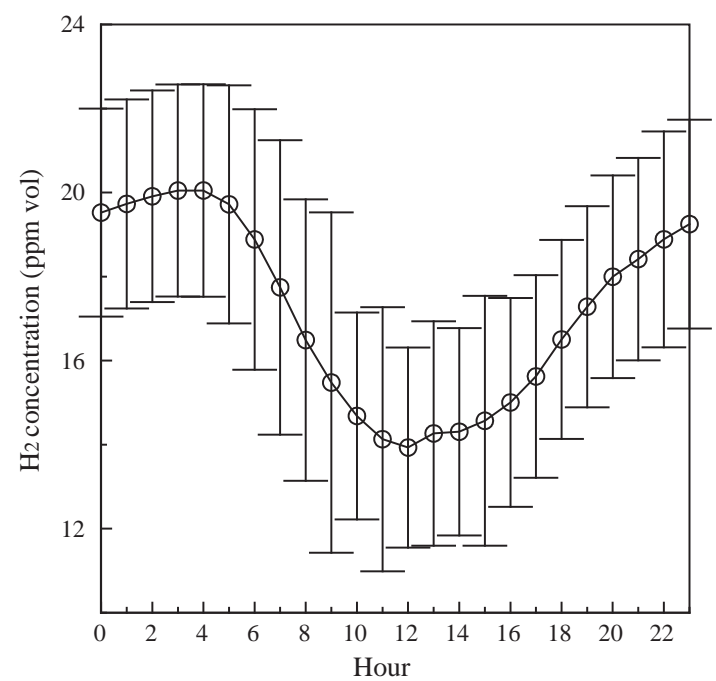

Fig. 9. $\mathrm{H}_{2}$ concentration vs daytime hours. The empty circles are the average concentration calculated for each hour considering the entire set of data collected from July 2009 to November 2010 .

activity of August 25th (INGV-PA; monitoring bulletin available at http://www.pa.ingv.it). According to Aiuppa et al. (2007), this indicates the magma migration toward shallower depths.

Furthermore, the raw data of $\mathrm{H}_{2}$ concentration exhibited a singular behavior starting from August 13th, 2010 (box in Fig. 6): they increase from background to anomalous values with amplitudes one order of magnitude larger than the daily cycles observed throughout the monitoring period. No such variations were observed in the $\mathrm{CO}_{2}$ flux data. This rules out the possibility that the $\mathrm{H}_{2}$ pulses could be due to an electric disturbance in the acquisition system. Moreover, as discussed above, the proper functioning of the device is proved by the repetitions of $\mathrm{H}_{2}$ measurements that arranged as shown in the Fig. 3a.

Anomalous $\mathrm{H}_{2}$ pulses can be explained as the result of an enhanced $\mathrm{H}_{2}$ loss from the gas-richer magma produced through the water dissociation reactions (Giammanco et al., 1998; Nuccio and Valenza, 1998). Since the $\mathrm{H}_{2}$ diffuses a million times faster than does $\mathrm{O}_{2}$ in silicate melts (Carmichael et al., 1974), the $\mathrm{H}_{2}$ loss triggers the temporary increase in oxygen fugacity of the magma. Nevertheless, several heterogeneous equilibria buffer the oxygen fugacity in the reservoir and the redox equilibrium of the magma is rapidly restored. As suggested by Aiuppa et al. (2011), the $\mathrm{H}_{2}$ produced by the magma through this mechanism migrate in gas bubbles, and then move quickly at shallower depths. Therefore, we infer that a departure from and restoration of the redox equilibrium in the magma reservoir could account for the shape of the $\mathrm{H}_{2}$ pulses observed at Mt Etna in August 2010.

Another possible explanation for the observed $\mathrm{H}_{2}$ pulses is that a large amount of $\mathrm{H}_{2}$ can be produced through steam formation and water dissociation at high temperature by the intersection of the magma fluids with the local aquifers (Giammanco et al., 1998; Pecoraino and Giammanco, 2005).

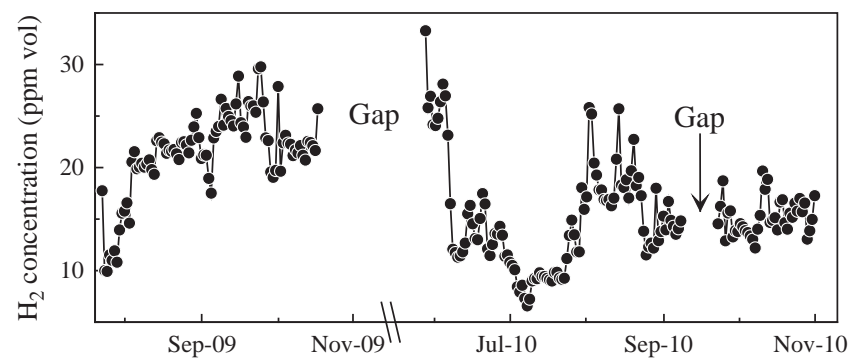

Fig. 10. Time series of the daily average $\mathrm{H}_{2}$ concentration (24 hours average) measured at BLV from July 2009 to November 2010. 
Nevertheless, our data do not allow us to discriminate among these alternative processes, both of which are possible.

In August 2010 Mt Etna showed increasing signs of unrest, with deep-sealed explosions without the emission of new eruptive products becoming increasingly frequent. The explosive activity that occurred on 25 August at Bocca Nuova (BN) produced a dark-gray ash column that rose 1-2 km above Mt Etna's summit. This ash had a lithic nature, comprised of $30-40 \%$ of juvenile material. Further explosions, internal collapses, and ash emissions occurred from the BN crater throughout the following days. The temporal relationship between the occurrence of the $\mathrm{H}_{2}$ pulses and the onset of the explosions from the BN crater can suggest that the high-frequency variations in the $\mathrm{H}_{2}$ concentration recorded at BLV could be magma-derived $\mathrm{H}_{2}$ pulses. Besides the $\mathrm{H}_{2}$ pulses, the daily average $\mathrm{H}_{2}$ concentration increased from late July to September 2010 (Fig. 10). These data as well as the higher $\mathrm{CO}_{2}$ flux (about $1000 \mathrm{~g} \mathrm{~m}^{-2}$ day $^{-1}$ ) could suggest a more reduced and gasricher magma batch that fed the fumarolic emissions from BLV before Mt Etna's explosive activity in August 2010. Moreover, this inference is consistent with the emission of juvenile materials during the explosions.

The last eruptive activity at the BN crater occurred during July 2006. Therefore, the explosions of August 2010, can be defined as the greatest volcanic activity recorded during the period of our observations, and it may represent a key event in the framework of the subsequent activity of Mt Etna. The SEC is far away from the BN crater, but geochemical and geophysical investigations (Marchetti et al., 2009; Aiuppa et al., 2010) have revealed a geometrical relationship between the central craters (BN and Voragine) and the SEC, defining a secondary branch of Mt Etna's shallow conduit system. In this framework, the central craters represent the preferential pathway for normal passive degassing, while an increase in the rate of gas or magma supply above some threshold activates degassing from the SEC (Marchetti et al., 2009). Moreover, Aiuppa et al. (2010) reported the upward and eastward migration of the source of the seismic tremor prior to the onset of the explosive activity at the SEC during 2007 and 2008. These observations provided evidence of magma migration from the shallow storage zone toward the SEC before the onset of paroxysmal activity.

\section{Conclusions}

A device for measuring the $\mathrm{H}_{2}$ concentration and $\mathrm{CO}_{2}$ flux has been designed, tested in the laboratory, and used for continuous monitoring at Mt Etna volcano. The results of using a fuel cell (Rew Power@ fuel cell - model 023) as an $\mathrm{H}_{2}$ sensor indicated that the detector has a sensitivity of $0.2 \mathrm{mV}$ (ppm vol) $)^{-1}$ for $\mathrm{H}_{2}$, a resolution of $\sim 10 \mathrm{ppm}$ vol, an accuracy of $\pm 5 \mathrm{ppm}$ vol, and response time shorter than $300 \mathrm{~s}$.

In order to investigate the cross-sensitivity effects on the $\mathrm{H}_{2}$ concentration measurements, several tests were performed with the main volatile components of volcanic and geothermal emissions $\left(\mathrm{CO}_{2}\right.$, $\mathrm{CH}_{4}, \mathrm{CO}$, and $\mathrm{H}_{2} \mathrm{~S}$ ). The results indicated that $\mathrm{H}_{2} \mathrm{~S}$ produces the largest cross-sensitivity effect, with a fourfold higher sensitivity per equivalent concentration of $\mathrm{H}_{2}$. However, the preliminary field test of the $\mathrm{H}_{2}$ sensor indicated that the use of an $\mathrm{H}_{2} \mathrm{~S}$ chemical trap (i.e., $\mathrm{Pb}\left(\mathrm{CH}_{3} \mathrm{COO}\right)_{2}$ ) was able to prevent the $\mathrm{H}_{2} \mathrm{~S}$ cross-sensitivity effect interfering with the $\mathrm{H}_{2}$ concentration measurement. The cross-sensitivity effects produced by other volatile components $\left(\mathrm{CO}_{2}, \mathrm{CH}_{4}\right.$, and $\left.\mathrm{CO}\right)$ were lower than $6 \%$ of the absolute $\mathrm{H}_{2}$ concentration.

The data obtained from the continuous monitoring of fumarolic emissions at Mt Etna has revealed a systematic relationship between $\mathrm{H}_{2}$ concentration and $\mathrm{CO}_{2}$ flux. The $\mathrm{CO}_{2}$ flux has often been characterized by long-term variations, while the $\mathrm{H}_{2}$ concentration exhibited daily variations and pulses. Daily variations within a few ppm vol were interpreted as the result of the reversal of the orographic wind direction, while $\mathrm{H}_{2}$ pulses having amplitudes larger than one order of magnitude of the daily variations were interpreted as the result of enhanced hydrogen loss from the magma or produced by the interaction of magma fluids with groundwaters.
Finally, this study gives important data and technical information to help in identifying the short-term tracers of the magma dynamics immediately before an eruptive event.

\section{Acknowledgements}

We would like to thank the reviewers for their constructive and helpful suggestions that improved the manuscript.

\section{Appendix A}

Fig. 5 shows a schematic representation of the $\mathrm{H}_{2}-\mathrm{CO}_{2}$ system. All its electronic and pneumatic components are hosted within a water-proof case of $58 \times 44 \times 22 \mathrm{~cm}$ (Explorer Cases), weighting about $5 \mathrm{~kg}$. A solar panel and a lead battery ( $12 \mathrm{~V}, 100 \mathrm{Ah}$ ) provide the power supply required for operating all the electric components. Two separate pneumatic systems were used for measuring $\mathrm{H}_{2}$ concentration and $\mathrm{CO}_{2}$ flux. In both the cases, the gas was sampled through a probe inserted into the soil at $50 \mathrm{~cm}$ depth and successively it passed through a water trap developed to eliminate the water vapor. In both cases, the gas was sucked by using a membrane pump and the intake flow was controlled and fixed by a fluxmeter. A PTFE filter (Acro® ${ }^{8}$, Pall Corporation) placed before the pump was used in both pneumatic systems in order to filter the dust and thus preserving the pumps and measurement sensors. Furthermore, in the case of the $\mathrm{H}_{2}$ measurement, the gas passed through a lead acetate trap for eliminating $\mathrm{H}_{2} \mathrm{~S}$, before entering the PTFE filter. This is a glass tube $10 \mathrm{~cm}$ long and $1 \mathrm{~cm}$ in diameter, filled with $\mathrm{Pb}\left(\mathrm{CH}_{3} \mathrm{COO}\right)_{2}$ powder. Therefore, the gas is injected at a constant flux of $0.5 \mathrm{~L} / \mathrm{min}$ into the anode (sensing electrode) of the fuel cell for $7 \mathrm{~min}$. At the same time a gas-bubbler allows saturating with water vapor the air entering the cathode (reference electrode) of the cell, ensuring a constant level of hydration of the Nafion ${ }^{\circledR}$ membrane. All the measurement operations were driven by a special data logger developed by INGV-Pa, equipped with an on-board programmable realtime clock. Data were hourly acquired and stored in the data logger (130 kB of onboard memory) and daily transmitted via modem-GSM to the database of the INGV-Pa. At the end of each measurement cycle, an electrovalve connected to the bottom of the water trap is switched on in order to remove the condensed water. Furthermore in order to evaluate the environmental effects on the measurement of both the $\mathrm{CO}_{2}$ flux and the $\mathrm{H}_{2}$ concentration, the station was equipped with a temperature and pressure transducer.

The software used for programming, collecting and storing into the database the acquired data was developed by INGV-Pa (Acquisition 2.0), while data were filtered using the Signal Processing Toolbox of the MATLAB $®$ software package. The power consumption of the system is of about $150 \mathrm{~mA}$. The values of the power consumption of each singular component measured in the laboratory are reported in Table A.1.

Table A. 1

Values of the power consumption of each component of the $\mathrm{H}_{2}-\mathrm{CO}_{2}$ device.

\begin{tabular}{ll}
\hline Component & Power consumption $(\mathrm{mA} / 12 \mathrm{~V})$ \\
\hline Pump & 50 at $0.5 \mathrm{~L} / \mathrm{min}$ \\
Electrovalve & 70 \\
IR & 420 \\
Data logger (quiescent mode) & $<5$ \\
Data logger (operating mode) & 70 \\
Modem (idle mode) & 40 \\
Modem (transmit mode) & 210
\end{tabular}




\section{References}

Aiuppa, A., Caleca, A., Federico, C., Gurrieri, S., Valenza, M., 2004. Diffuse degassing of carbon dioxide at Somma-Vesuvius volcanic complex (Southern Italy) and its relation with regional tectonics. J. Volcanol. Geotherm. Res. 133, 55-79.

Aiuppa, A., Moretti, R., Federico, C., Giudice, G., Gurrieri, S., Liuzzo, M., Papale, P., Shinohara, H., Valenza, M., 2007. Forecasting Etna eruption by real-time observation of volcanic gas composition. Geology 35, 1115-1118. http://dx.doi.org/10.1130 G24149A.1.

Aiuppa, A., Cannata, A., Cannavò, F., Di Grazia, G., Ferrari, F., Giudice, G., Gurrieri, S., Liuzzo, M., Mattia, M., Montalto, P., Patanè, D., Puglisi, G., 2010. Patterns in the recent 2007-2008 activity of Mount Etna volcano investigated by integrated geophysical and geochemical observations. Geochem. Geophys. Geosyst. 11. http://dx.doi.org/10.1029/2010GC003168.

Aiuppa, A., Shinohara, H., Tamburello, G., Giudice, G., Liuzzo, M., Moretti, R., 2011. Hydrogen in the gas plume of an open-vent volcano, Mount Etna, Italy. J. Geophys. Res. 116. http://dx.doi.org/10.1029/2011JB008461.

Allard, P., Carbonnelle, J., Dajlevic, D., Le Bronec, J., Morel, P., Robe, M.C., Maurenas, J.M. Faivre-Pierret, R., Martin, D., Sabroux, J.C., Zettwoog, P., 1991. Eruptive and diffuse emissions of $\mathrm{CO}_{2}$ from Mount Etna. Nature 351, 387-391.

Badalamenti, B., Gurrieri, S., Hauser, S., Tonani, F., Valenza, M., 1984. Considerazioni sulla concentrazione e sulla composizione isotopica della $\mathrm{CO}_{2}$ presente nelle manifestazioni naturali e nell'atmosfera dell'isola di Vulcano. Rend. Soc. Ital. Mineral. Petrol. 39, 367-378.

Badalamenti, B., Gurrieri, S., Hauser, S., Parello, F., Valenza, M., 1988. Soil CO 2 output in the island of Vulcano during the period 1984-1988: surveillance of gas hazard and volcanic activity. Rend. Soc. Ital. Mineral. Petrol. 43, 893-899.

Badalamenti, B., Gurrieri, S., Hauser, S., Parello, F., Valenza, M., 1991. Change in the soil $\mathrm{CO}_{2}$ output at Vulcano during the summer 1998. Acta Vulcanol. 1, 219-221.

Badalamenti, B., Capasso, G., Carapezza, M.L., D'Alessandro, W., Di Gangi, F., Diliberto, I.S., Giammanco, S., Gurrieri, S., Nuccio, P.M., Parello, F., Valenza, M., 1994. Soil gas investigations during the 1991-1993 Etna eruption. Acta Vulcanol. 4, 135-141.

Barberi, F., Carapezza, M.L., 1994. Helium and $\mathrm{CO}_{2}$ soil gas emission from Santorini (Greece). Bull. Volcanol. 56, 335-342.

Baubron, J.C., Allard, P., Sabroux, J.C., Tedesco, D., Toutain, J.P., 1991. Soil gas emanations as precursory indicators of volcanic eruptions. J. Geol. Soc. (Lond.) 148, 571-576.

Benhamou, G., Allard, P., Sabroux, J.C., Vitter, G., Dajlevic, D., Creusot, A., 1988. Oxygen fugacity of gases and rocks from Momotombo volcano, Nicaragua: application to volcanological monitoring. J. Geophys. Res. 93, 14872-14880.

Bertami, R., Buonasorte, G., Ceccarelli, A., Lombardi, S., Pieri, S., Scandiffio, G., 1990. Soil gases in geothermal prospecting: two case histories (Sabatini Volcanoes and Alban hills, Latium, central Italy). J. Geophys. Res. 95, 475-481.

Camarda, M., Gurrieri, S., Valenza, M., 2006. $\mathrm{CO}_{2}$ flux measurements in volcanic areas using the dynamic concentration method: the influence of the soil permeability. J. Geophys. Res. 111. http://dx.doi.org/10.1029/2005JB003898.

Camarda, M., De Gregorio, S., Gurrieri, S., 2012. Magma-ascent processes during 2005-2009 at Mt Etna inferred by soil $\mathrm{CO}_{2}$ emissions in peripheral areas of the volcano. Chem. Geol. 330-331, 218-227. http://dx.doi.org/10.1016/j.chemgeo.2012.08.024.

Candela, P.A., 1986. The evolution of aqueous vapour from silicate melts: effect on oxygen fugacity. Geochim. Cosmochim. Acta 50, 1205-1211.

Carapezza, M.L., Barberi, F., Ranaldi, M., Ricci, T., Tarchini, L., Barranco, S.J., Fischer, C., Perez, N., Weber, K., Di Piazza, A., Gattuso, A., 2011. Diffuse $\mathrm{CO}_{2}$ soil degassing and $\mathrm{CO}_{2}$ and $\mathrm{H}_{2} \mathrm{~S}$ air concentration and related hazard at Vulcano Island (Aeolian arc, Italy). J. Volcanol. Geoth. Res. 207, 130-144.

Carmichael, I.S.E., Ghiorso, M.S., 1986. Oxidation-reduction relations in basic magma: a case for homogeneous equilibria. Earth Planet. Sci. Lett. 78, 200-210.

Carmichael, I.S.E., Turner, F.J., Verhoogen, J., 1974. Igneous Petrology. McGraw-Hill Book Co., New York (739 pp.).

Chiodini, G., Cioni, R., Guidi, M., Raco, B., Marini, L., 1998. Soil $\mathrm{CO}_{2}$ flux measurements in volcanic and geothermal areas. Appl. Geochem. 13, 543-552.

D'alessandro, W., Giammanco, S., Parello, F., Valenza, M., 1997. $\mathrm{CO}_{2}$ output and $\delta^{13} \mathrm{C}\left(\mathrm{CO}_{2}\right)$ from Mount Etna as indicators of degassing of shallow asthenosphere. Bull. Volcanol. $58,455-458$.

Favalli, M., Mazzarini, F., Pareschi, M.T., Boschi, E., 2004. Role of local wind circulation in plume monitoring at Mt. Etna volcano (Sicily): insights from a mesoscale numerical model. Geophys. Res. Lett. 31. http://dx.doi.org/10.1029/ 2003GL019281.

Federico, C., Camarda, M., De Gregorio, S., Gurrieri, S., 2011. Long-term record of $\mathrm{CO}_{2}$ degassing along Mt. Etna's flanks and its relationship with magma dynamics and eastern flank instability. Geochem. Geophys. Geosyst. 12. http://dx.doi.org/10.1029/ 2011GC003601.

Finlayson, J.B., 1992. A soil gas survey over Rotorua geothermal field, Rotorua, New Zeland. Geothermal 21, 181-195.

Fudali, R.F., 1965. Oxygen fugacity of basaltic and andesitic magmas. Geochim. Cosmochim. Acta 29, 1063-1075.

Gerlach, T.M., 1983. Intrinsic chemical variations in high-temperature gases from basic lavas. In: Tazieff, H., Sabroux, J.C. (Eds.), Forecasting Volcanic Events. Elsevier, Amsterdam, pp. 323-336.

Gerlach, T.M., 1991. Present-day $\mathrm{CO}_{2}$ emissions from volcanoes. Eos Trans. AGU 72, 254-255.

Giammanco, S., Gurrieri, S., Valenza, M., 1995a. Soil $\mathrm{CO}_{2}$ degassing from the ground on mount Etna during 1992. Acta Vulcanol. 6, 7-9.

Giammanco, S., Gurrieri, S., Valenza, M., 1995b. Soil $\mathrm{CO}_{2}$ degassing on Mt Etna (Sicily) during 1989-1993: discrimination between climatic and volcanic influences. Bull. Volcanol. 57, 52-60.
Giammanco, S., Gurrieri, S., Principio, E., Valenza, M., 1996. CO 2 fluxes from Mt. Etna soils. Acta Vulcanol. 8, 220-222.

Giammanco, S., Gurrieri, S., Valenza, M., 1997. Soil $\mathrm{CO}_{2}$ degassing along tectonic structure of Mt. Etna Sicily: the Pernicana Fault. Appl. Geochem. 12, 429-436.

Giammanco, S., Inguaggiato, S., Valenza, M., 1998. Soil and fumarole gases of Mount Etna: geochemistry and relations with volcanic activity. J. Volcanol. Geotherm. Res. 81, 297-310.

Giammanco, S. Gurrieri, S., Valenza, M. 2006. Fault-controlled soil $\mathrm{CO}_{2}$ degassing and shallow magma bodies: summit and lower East Rift of Kilauea volcano (Hawaii), 1997. Pageophysic 163, 853-867.

Giammanco, S., Sims, K.W.W., Neri, M., 2007. Measurements of ${ }^{220} \mathrm{Rn}$ and ${ }^{222} \mathrm{Rn}$ and $\mathrm{CO}_{2}$ emissions in soil and fumarole gases on Mt. Etna volcano (Italy): implications for gas transport and shallow ground fracture. Geochem. Geophys. Geosyst. 8, Q10001. http://dx.doi.org/10.1029/2007GC001644.

Giammanco, S., Bellotti, F., Groppelli, G., Pinton, A. 2010. Statistical analysis reveals spatia and temporal anomalies of soil $\mathrm{CO}_{2}$ efflux on Mount Etna Volcano. J. Volcanol. Geotherm. Res. 194, 1-14.

Giggenbach, W.F., 1987. Redox processes governing the chemistry of fumarolic gas discharges from White Island, New Zeland. Appl. Geochem. 2, 143-161.

Granieri, D., Chiodini, G., Marzocchi, W., Avino, R., 2003. Continuous monitoring of $\mathrm{CO}_{2}$ soil diffuse degassing at Phlegraean Fields (Italy): influence of environmental and volcanic parameters. Earth Planet. Sci. Lett. 212, 167-179.

Granieri, D., Avino, R., Chiodini, G., 2009. Carbon dioxide diffuse emission from the soil: ten years of observations at Vesuvio and Campi Flegrei (Pozzuoli), and linkages with volcanic activity. Bull. Volcanol. 72, 103-118.

Gregory, R.G., Durrance, E.M., 1985. Helium, carbon dioxide and oxygen soil gases: smallscale variations over fractured ground. J. Geochem. Explor. 24, 29-49.

Gurrieri, S., Valenza, M., 1988. Gas transport in natural porous mediums: a method for measuring $\mathrm{CO}_{2}$ flows from the ground in volcanic and geothermal areas. Rend. Soc. Ital. Mineral. Petrol. 43, 1151-1158.

Heald, E.F., Naughton, J.J., Barnes, I.L., 1963. The chemistry of volcanic gases, 2, Use of equilibrium calculations in the interpretation of volcanic gas samples. J. Geophys. Res. 68, 545-557.

Irwin, W., Barnes, I., 1980. Tectonic relations of carbon dioxide discharges and earthquakes. J. Geophys. Res. 85, 3115-3121.

Kameda, J., Saruwatari, K., Tanaka, H., 2003. $\mathrm{H}_{2}$ generation in wet grinding of granite and single-crystal powders and implications for $\mathrm{H}_{2}$ concentration on active faults. Geophys. Res. Lett. 30. http://dx.doi.org/10.1029/2003GL018252.

Kamenetsky, V.S., Pompilio, M., Métrich, N., Sobolev, A.V., Kuzmin, D.V., Thomas, R., 2007. Arrival of extremely Volatile-rich high-Mg magmas changes explosivity of Mount Etna. Geology 35, 255-258 http://dx.doi.org/10.1130/G23163A.1.

King, C., 1980. Episodic radon changes in subsurface soil gas along active faults and possible relation to earthquakes. J. Geophys. Res. 85, 3065-3078.

Marchetti, E., Ripepe, M., Ulivieri, G., Caffo, S., Privitera, E., 2009. Infrasonic evidences for branched conduit dynamics at Mt. Etna volcano, Italy. Geophys. Res. Lett. 36. http:// dx.doi.org/10.1029/2009GL040070.

McCarthy, J.H., Reimer, G.M., 1986. Advances in soil gas geochemical Exploration for natural resources: some current examples and practice. J. Geophys. Res. 91, 327-338.

Mehta, V., Cooper, J.S., 2003. Review and analysis of PEM fuel cell design and manufacturing. J. Power Sources 114, 32-53.

Moretti, R., Papale, P., 2004. On the oxidation state and volatile behaviour in multicomponent gas-melt equilibria. Chem. Geol. 213 (1-3), 265-280.

Nuccio, P.M., Valenza, M., 1998. Magma degassing and geochemical detection of its ascent. Water-Rock, Interaction, WRI-9, pp. 471-474.

Oskarsson, N., 1984. Monitoring of fumarole discharge during the 1975-1982 rifting in Krafla volcanic center, North Iceland. J. Volcanol. Geoth. Res. 22, 97-121.

Pecoraino, G., Giammanco, S., 2005. Geochemical characterization and temporal changes in parietal gas emissions at Mt. Etna (Italy) during the period July 2000-July 2003. TAO 16, 805-841.

Salazar, J.M.L., Perez, N.M., Hernandez, P.A., Soriano, T., Barahona, F., Olmos, R., Cartagena, R., Lopez, D.L., Lima, R.N., Melian, G., 2002. Precursory diffuse carbon dioxide degassing signature related to a 5.1 magnitude earthquake in El Salvador, Central America. Earth Planet. Sci. Lett. 205, 81-89.

Satake, H., Ohashi, M., Hayashi, Y., 1984. Discharge of $\mathrm{H}_{2}$ from atotsugawa and Ushikubi faults, Japan, and its relation to earthquakes. Pageophysics 122 $185-193$.

Sato, M., 1978. Oxygen fugacity of basaltic magmas and the role of gas-forming elements. Geophys. Res. Lett. 5, 447-449.

Sato, M., McGee, K.A., 1982. Continuous monitoring of hydrogen on south flank of Mount St. Helens. In: Lipman, P.W. Mullineaux, D. R. (Eds.), The 1980 eruption of Mount St. Helens. Washington, Geological Survey Professional Paper, 1250, pp. 209-219.

Sato, M., Moore, J.G., 1973. Oxygen and Sulphur fugacities of magmatic gases directly measured in active vents of Mount Etna. Philos. Trans. R. Soc. Lond. 274, 137-146.

Sato, M., Sutton, A.J., McGee, K.A., 1984. Anomalous hydrogen emissions from San Andreas fault observed at the Cienega Winery, Central California. Pageophysics 122, 366-391.

Sinclair, A.J., 1974. Selection of threshold values in geochemical data using probability graphs. J. Geochem. Explor. 3, 129-149.

Sugisaki, R., Ido, M., Takeda, H., Isobe, Y., Hayashi, Y., Nakamura, N., Satake, H., Mizutani, Y., 1983. Origin of hydrogen and carbon dioxide in fault gases and its relation to fault activity. J. Geol. 3, 239-258.

Valenza, M., 1993. Preliminary study on emanation of $\mathrm{CO}_{2}$ from soils in some areas of Mount Etna (Sicily). Acta Vulcanol. 3, 189-194. 
Valenza, M., 1994. Soil gas investigations during the 1991-1993 Etna eruption. Acta Vulcanol. 4, 135-141.

Wakita, H., 1996. Geochemical challenge to earthquake prediction. Proc. Natl. Acad. Sci. U. S. A. 93, 3781-3786

Wakita, H., Nakamura, Y., Kita, I., Fujii, N., Notsu, K., 1980. Hydrogen release: new indicator of fault activity. Science $210,188-190$.
Zhdanov, V.P., 2007. Simulations of processes related to $\mathrm{H}_{2}-\mathrm{O}_{2}$ PEM fuel cells. J. Electroanal. Chem. 607, 17-24.

Zhu, M., Wadge, G., Holley, R., James, I.N., Clark, P.A., Wang, C.G., Woodage, M.J., 2008. Structure of the precipitable water field over Mount Etna. Tellus Ser. A Dyn. Meteorol. Oceanogr. 60A, 679-687. http://dx.doi.org/10.1111/j.16000870.2008.00317.x. 